\title{
MODEL PEMBERDAYAAN PEREMPUAN DAN PENGARUSUTAMAAN GENDER MELALUI LAYANAN PENDIDIKAN MASYARAKAT PADA PUSAT KEGIATAN BELAJAR MASYARAKAT
}

\author{
Anan Sutisna \\ FIP Universitas Negeri Jakarta \\ email: ananpls@yahoo.com
}

\begin{abstract}
Abstrak: Penelitian ini bertujuan untuk mendeskripsikan model pemberdayaan perempuan dan pengarusutamaan gender melalui layanan pendidikan masyarakat pada Pusat Kegiatan Belajar Masyarakat di DKI Jakarta. Penelitian menggunakan metode survei, teknik pengumpulan data melalui penyebaran angket, dan teknik analisis data menggunakan statistik deskriptif. Hasil penelitian menunjukkan hal-hal sebagai berikut. (1) Layanan program pendidikan masyarakat yang paling banyak diikuti oleh responden adalah pendidikan kesetaraan $(61,4 \%)$, dan jenis kelamin responden dalam penelitian ini adalah perempuan (75,8\%). (2) Pemberdayaan perempuan dan pengarusutamaan gender melalui pendidikan masyarakat (61,5\%). (3) Model pemberdayaan perempuan dan pengarusutamaan gender melaui pendidikan masyarakat, dipandang strategis dengan pengintegrasian berbagai program yang direncanakan oleh pemerintah dengan program life skill sehingga akan menghasilkan sumberdaya manusia yang berakhalak mulia, cerdas, terampil dan mandiri.
\end{abstract}

Kata Kunci: model pemberdayaan perempuan, layanan Pendidikan masyarakat

\section{A MODEL OF WOMAN EMPOWERMENT AND GENDER MAINSTREMING THROUGH COMMUNITY EDUCATIONAL SERVICE IN THE COMMUNITY LEARNING ACTIVITY CENTER}

\begin{abstract}
This study was aimed to describe a model of woman empowerment and gender mainstreaming through the community educational service in the community learning activity center in Greater Jakarta Special Capital Region. This study employed the survey method. The data were collected through questionnaires and were analyzed using the descriptive statistics. The findings showed the following: (1) the community educational program service mostly joined by the respondents was the equality education (61.4\%), and most of the respondents were female (75.8\%). (2) The woman empowerment and gender mainstreaming was carried out through the community education (61.5\%). (3) The model of woman empowerment and gender mainstreaming through the community education is considered as being strategic with the integration of various programs planned by the government with the life skill program to produce human resources with the good character, being intelligent, skillful, and self-dependent.
\end{abstract}

Keywords: model of woman empowerment, community educational service

\section{PENDAHULUAN}

Di Indonesia, pada tahun 2006 sekitar 5.39 juta orang tidak bisa baca tulis (buta huruf) terdiri atas 2,80 juta orang usia $10-44$ tahun dan 2,59 juta orang usia 44 tahun ke atas. Penyandang buta aksara tertinggi $65 \%$ adalah kaum perempuan karena keterbatasan perempuan dan rendahnya tingkat pendidikan, sehingga kurang pemahaman dan pengetahuan mengakibatkan banyak masalah, (Depdiknas, 2006). Misalnya, korban trafficking (perda- gangan orang), narkoba, tindak kekerasan rumah tangga dan lain sebagainya. Begitu juga di bidang ketenagakerjaan masih terjadi kesenjangan pada tingkat partisipasi angkatan kerja, tingkat upah yang diterima, kekerasan terhadap tenaga kerja perempuan yang bekerja di luar negeri atau predikat negara pengirim tenaga kerja wanita tertinggi dengan perlindungan minim, pekerja tidak dibayar, dan pekerja informal. 
Masalah pemahaman terhadap kesehatan perempuan Indonesia masih rendah. Hal ini terlihat dari beberapa indikator antara Angka Kematian Ibu (AKI) saat itu masih tertinggi di banding negara-negara lain di ASEAN. Permasalahan tersebut disebabkan oleh faktor status kesehatan reproduksi, status gizi ibu sebelum dan selama kehamilan, ekonomi keluarga yang rendah serta status dan kedudukan perempuan yang rendah dalam masyarakat. Isu lain yang tidak kalah menariknya adalah rentannya perempuan terhadap Penyakit menular (HIV/AIDS) terutama daerah padat penduduk, perbatasan dan daerah wisata karena kurangnya pengetahuan HIV/AIDS (Kompas, 12 Maret 2011).

Keterbatasan dalam pengetahuan serta adanya perbedaan antara laki-laki dengan perempuan semakin membuat parah kaum perempuan di Indonesia. Hal ini membuat perempuan tidak berdaya. Misalnya, dilihat dari segi adat yang berlaku di masyarakat adat yakni patrilineal, matrilineal dan bilateral. Pada masyarakat patrilineal seperti Suku Batak, Lampung dan Flores, anak laki-laki akan menjadi pewaris serta kepala keluarga pengganti ayah. Padahal perempuan di sana dominan dalam mencari nafkah dengan mengurus ladang, rumah serta pekerja lainnya. Dalam pengambilan keputusan perempuan tidak punya hak memberikan saran maupun pendapat. Manakala (paman laki-laki) yang memiliki kekuasaan pengaturannya, seringkali paman juga ikut mengambil bagian dari warisan tersebut, dan bahkan menguasainya. Ada pun dalam masyarakat bilateral, seperti di Jawa lebih pada menerima anak ragil atau paling kecil yang biasa menemani kedua orang tuanya.

Perbedaan yang paling nyata dialami oleh masyarakat sekarang masih terlihat adalah pada kegiatan di masyarakat. Misalnya, acara rapat RT/RW selalu diwakili kepala keluarga atau kaum laki-laki. Hanya sebagian kecil perempuan yang dilibatkan dalam pengambilan keputusan dalam lingkup masyarakat. Proses pembangunan yang dilaksanakan keterlibatan perempuan hanya sebatas melihat, mengamati serta menerima hasil pembangunan. Keter- libatan dalam proses serta informasi perempuan hanya urutan kedua setelah laki-laki. Oleh karena itu, perlu adanya suatu program yang khusus serta lembaga yang dapat digunakan sebagai wadah tempat perempuan mengimplementasikan kemampuannya dalam merencanakan, melaksanakan dan mengevaluasi kegiatan yang mendukung pembangunan.

Pendidikan nonformal merupakan salah satu alternatif yang mampu melakukan proses pemberdayaan, melalui berbagai program pendidikan masyarakat yang dapat menjembatani perempuan dalam meningkatkan kualitas pengetahuan dan kemandirian (Kindervatter, 1979). Hadirnya pendidikan masyarakat sebagai alternatif pendidikan formal untuk memenuhi kebutuhan perempuan dalam rangka mendukung pendidikan sepanjang hayat, di mana tujuannya mengembangkan potensi peserta didik dengan penekanan pada penguasaan pengetahuan dan keterampilan fungsional serta pengembangan sikap dan kepribadian profesional.

Proses perberdayaan yang dilakukan untuk meningkatkan kualitas perempuan melalui layanan program pendidikan masyarakat antara lain: Kegiatan Keaksaraan Fungsional, Kelompok Belajar Keterampilan (KBK), Kelompok Belajar Usaha (KBU), Taman Bacaan Masyarakat (TBM), Kecakapan Hidup (Life Skills), dan sejenisnya dengan mempergunakan seperangkat modul/instrumen pembelajaran yang ada di PKBM baik di desa maupun di kota seluruh Indonesia (Sihombing, 2000).

Program pemberdayaan perempuan dan pengarustamaan gender mengalami peningkatan dapat diukur dengan menggunakan Gender Development Indek (GDI) dan Indeks Pemberdayaan Gender (GEM). Pada tahun 2004 GDI Nasional 63,9 meningkat menjadi 66,38 pada tahun 2008. Kemudian GEM pada tahun 2004 sebesar 59,7 meningkat menjadi 62,27 pada tahun 2008. Rasio kesetaraan gender dalam Penuntasan Buta Aksara $97.3 \%$ pada tahun 2009, sedangkan persentasi Kab/Kota pengarustamakan gender 5\% (Kemendiknas: 2010). Padahal sudah didukung oleh Inpres Nomor 9 tahun 2000 tentang Pengarusutamaan gender (PUG) yang menginstruksikan kepada seluruh 
pejabat Negara, termasuk Gubernur, Bupati/ Walikota untuk melaksanakan PUG di seluruh wilayah Indonesia. Bahkan dalam Program pembangunan nasional (Propernas), menyatakan bahwa pembangunan nasional harus berperspektif gender, sebagai upaya konkrit untuk mewujudkan kesetaraan dan keadilan gender dalam kehidupan berkeluarga, bermasyarakat, dan bernegara, (UU No. 25/2000).

Strategi pelaksanaan program pemberdayaan perempuan melalui layanan pendidikan masyarakat diharapkan dapat mendukung pelaksanaan komitmen pemerintah terhadap konvensi internasional mengenai pendidikan, khususnya Konvensi Dakar tentang Pendidikan untuk Semua (Education For All), Konvensi Hak Anak (Convention on the Right of Child), Millenium Development Goals (MDGs), dan World Summit on Sustainable Development. Oleh karena itu, pemerintah melalui Pendidikan Masyarakat berkewajiban melaksanakan pendidikan yang mampu menjangkau kalangan orang dewasa, sehingga orang dewasa memperoleh pendidikan berkelanjutan khususnya perempuan untuk lebih berdaya (Yulaelawati, 2009). Untuk itu, perlu penelitian tentang pemberdayaan perempuan dan pengarusutamaan gender melalui layanan pendidikan masyarakat pada PKBM.

Berdasarkan latar belakang yang ada terutama berkaitan dengan pemberdayaan perempuan melalui layanan pendidikan masyarakat, kajian ini dibatasi pada masalah (1) layanan pendidikan masyarakat yang ada di PKBM, (2) model pemberdayaan perempuan dan pengarusutamaan gender. Variabel prediktor adalah tingkat keterjangkauan perempuan dalam mengakses program-program pendidikan masyarakat yang ada pada PKBM di DKI Jakarta.

\section{METODE}

Metode penelitian yang digunakan adalah survei dengan teknik deskriptif. Penelitian ini diarahkan guna memberi gambaran secermat mungkin mengenai individu, suatu keadaan, gejala maupun kelompok tertentu. Pengkajian ini merupakan jenis penelitian deskriptif (Sugiyono, 2007). Dalam hal ini untuk meng- gambarkan tentang model pemberdayaan perempuan dan pengarusutamaan gender melaui layanan program pendidikan masyarakat pada PKBM di DKI Jakarta.

Penelitian ini dilakukan pada Pusat Kegiatan Belajar Masyarakat (PKBM) di Provinsi DKI Jakarta, sebanyak 25 PKBM yang berada di lima wilayah kota yaitu: (1) Jakarta Pusat = 6 PKBM, (2) Jakarta Timur = 6 PKBM, (3) Jakarta Utara $=5$ PKBM, (4) Jakarta Selatan $=6$ PKBM dan (5) Jakarta Barat 2 PKBM. Waktu penelitian selama 5 bulan terhitung mulai Bulan Agustus sampai dengan Bulan Desember 2012.

Berkenaan dengan penelitian tentang model pemberdayaan perempuan melalui layanan pendidikan masyarakat, maka peneliti perlu menjabarkan secara mendetail variabel penelitian sebagai fokus permasalahan yang menjadi titik sentra pengungkapan. Beberapa variabel yang merupakan fokus garapan penelitian ini adalah (1) layanan pendidikan masyarakat dan (2) model pemberdayaan perempuan. Adapun definisi operasional dari dua konsep tersebut adalah sebagai berikut.

- Layanan pada dasarnya adalah aktivitas yang bertujuan untuk membantu masyarakat yang membutuhkan bantuan. Adapun bentuk layanan terhadap masyarakat berbeda, sesuai dengan kebutuhannya. Bentuk pelayanan yang diberikan berupa produk maupun Jasa (pendidikan). Pendidikan masyarakat adalah segala aktivitas yang dilakukan oleh anggota masyarakat dalam meningkatkan pengetahuan, sikap dan keterampilan yang sesuai dengan kebutuhan mendesak melalui pelatihan, kursus keterampilan.

- Model adalah suatu penyajian fisik atau konseptual dari suatu objek atau sistem yang mengkombinasikan bagian-bagian khusus tertentu dari objek aslinya, Fred (Hamalik, 2000:2). Pemberdayaan merupakan suatu proses, cara, perbuatan membuat berdaya, yaitu kemampuan untuk melakukan sesuatu atau kemampuan bertindak yang berupa akal, ikhtiar atau upaya (Depdiknas, 2003). Jadi, model pemberdayaan perempuan adalah suatu konsep atau sistem instruksional atau pembelajaran untuk 
mengembangkan pola perilaku perempuan dalam bidang pengetahuan, keterampilan atau sikap untuk mencapai tujuan.

Populasi penelitian ini adalah Pusat Kegiatan Belajar Masyarakat (PKBM) di DKI Jakarta sebanyak 154 berdasarkan data BAN PNF tahun 2010. Pengambilan sampel dilakukan secara purposive dengan kriteria PKBM pelat merah (negeri) sebanyak 9 dan PKBM swasta sebanyak 16. Jumlah sampel 25 PKBM. Masing-masing PKBM yang menjadi responden adalah satu orang penanggung jawab PKBM dan empat orang warga belajar. Dengan demikian jumlah responden seluruhnya sebanyak 91 orang.

Pengumpulan data dilakukan melalui angket yang berisi layanan program-program yang dimiliki oleh PKBM dan apakah program tersebut dapat diakses oleh perempuan untuk pemberdayaan masyarakat. Untuk mengetahui layanan program pendidikan di PKBM, digunakan indikator-indikator sebagai berikut: (1) perencanaan program layanan; (2) prioritas program layanan, (3) program layanan yang bersifat topdown; (4) pelibatan stakeholder; (5) prosedur layanan; (6) dampak perencanaan program; (7) perangkat layanan; (8) output program; (9) proses layanan; (10) standar layanan minimal; (11) mitra program; (12) program unggulan; (13) monitoring dan evaluasi program; (14) kriteria keberhasilan; (15) program yang distop; (16) sanksi kegagalan program; (17) evaluasi dampak; (18) program sesuai dengan visi; (19) sumber daya manusia dan sarana; dan (20) prestasi lembaga.

Untuk model pemberdayaan perempuan, angket yang diberikan kepada meliputi indikator: (1) aktif mengikuti kegiatan; (2) pernah men- jadi pengurus; (3) proaktif dalam kegiatan; (4) aktif memberikan saran; (5) sosialisasi kegiatan; (6) memperhatikan masalah; (7) berperan aktif; (8) memberikan pemikiran positif; (9) mengajak orang lain untuk ikut; (10) memiliki ide baru; (11) mengatasi masalah; (12) berpikir untuk lebih maju; (13) memberikan saran perbaikan; (14) kepuasan terhadap hasil; (15) menambah percaya diri; (16) memiliki keterampilan hidup; (17) program sesuai dengan kebutuhan; dan (18) manfaat program.

Analisis data menggunakan statistik deskriptik lewat penghitungan persentase yang akan digunakan untuk mendeskripsikan atau menjelaskan fenomena yang terjadi.

\section{HASIL DAN PEMBAHASAN}

Penelitian ini bertujuan (1) untuk memperoleh gambaran tentang program-program layanan pendidikan masyarakat yang dapat diakses perempuan dan pengarusutamaan gender yang berkualitas dan berkesinambungan; dan (2) untuk menganalisis model pemberdayaan Perempuan dan Pengarusutama Gender melalui layanan pendidikan masyarakat pada PKBM di DKI Jakarta.

Deskripsi hasil kegiatan pengumpulan data tentang layanan pendidikan masyarakat dalam pemberdayaan perempuan di PKBM hasilnya diuraikan sebagai berikut.

\section{Identitas Responden}

Identitas responden yang meliputi kualifikasi pendidikan, umur, jenis kelamin, pekerjaan, dan layanan program pendidikan disajikan pada Tabel 1- Tabel 5.

\section{Tabel 1. Kualifikasi Pendidikan Responden}

\begin{tabular}{llll}
\hline Nomor & Jenjang Pendidikan & Jumlah & Persentase \\
\hline 1. & Diploma/Sarjana & 2 & $2,2 \%$ \\
2. & SMA & 13 & $14,3 \%$ \\
3. & SMP & 56 & $61,5 \%$ \\
4. & SD & 20 & $22,0 \%$ \\
Jumlah & & 91 & 100 \\
\hline
\end{tabular}


Tabel 2. Umur Responden

\begin{tabular}{llll}
\hline Nomor & Umur & Jumlah & Persentase \\
\hline 1. & $12-15$ tahun & 23 & 25,3 \\
4. & $16-18$ tahun & 43 & 47,3 \\
7. & $19-28$ tahun & 13 & 14,3 \\
12. & $30-35$ tahun & 5 & 5,5 \\
16. & $42-50$ tahun & 7 & 7,7 \\
Jumlah & & 91 & 100 \\
\hline
\end{tabular}

Tabel 3. Jenis Kelamin Responden

\begin{tabular}{llll}
\hline Nomor & Jenis Kelamin & Jumlah & Persentase \\
\hline 1. & Laki-laki & 22 & 24.2 \\
2. & Perempuan & 69 & 75.8 \\
Jumlah & & 91 & 100 \\
\hline
\end{tabular}

Tabel 4: Pekerjaan Responden

\begin{tabular}{llll}
\hline Nomor & Jenis Pekerjaan & Jumlah & Persentase \\
\hline 1. & Baby Sister & 3 & 3.3 \\
2. & Pedagang & 1 & 1.1 \\
3. & Ibu Rumah Tangga & 6 & 6.6 \\
4. & Jaga Toko & 2 & 2.2 \\
5. & Karyawan & 4 & 4.4 \\
6. & Pedagang & 2 & 2.2 \\
7. & Pelajar & 49 & 53.8 \\
8. & Pembantu & 6 & 6.6 \\
9. & Pengamen & 11 & 12.1 \\
10. & Swasta & 5 & 5.5 \\
11. & Tidak bekerja & 2 & 2.2 \\
Jumlah & & 91 & 100 \\
\hline
\end{tabular}

Tabel 5: Layanan Program Pendidikan Masyarakat

\begin{tabular}{llll}
\hline Nomor & Layanan Program & Jumlah & Prosentase \\
\hline 1 & Keterampilan & 31 & 27.2 \\
2 & Kursus & 12 & 10.5 \\
3 & Pendidikan Keaksaraan & 1 & 0.9 \\
4 & Pendidikan Kesetaraan & 70 & 61,4 \\
Jumlah & & 114 & 100.0 \\
\hline
\end{tabular}




\section{Layanan Pendidikan Masyarakat}

Hasil analisis data layanan pendidikan masyarakat pada PKBM, berdasarkan sampel yang disurvei pada penelitian ini dapat dideskripsikan sebagai berikut.

- Perencanaan program layanan dalam pendidikan masyarakat di PKBM dapat dilakukan melalui rapat internal lembaga atau rapat koordinasi dengan instansi lain. Hal ini dari data survei menunjukkan $87,5 \%$ selalu dilakukan secara periodik.

- Prioritas program layanan pada pendidikan masyarakat di PKBM, menunjukkan 83,3\% selalu dilakukan dalam upaya menuju pelayanan yang prima.

- Program layanan yang bersifat Topdown dalam pendidikan masyarakat yang ada pada PKBM menunjukkan 41,7\% selalu. Hal ini berarti masih besarnya peran pemerintah dalam program pendidikan masyarakat dari atas.

- Melibatkan Stakeholder dalam perencanaan pelayanan pendidikan masyakat pada PKBM menunjukkan $70,8 \%$ yang menyatakan selalu. Hal ini berarti agar pelayanan pendidikan masyarakat dapat berjalan secara optimal.

- Prosedur layanan dalam pendidikan masyarakat semestinya ada. Oleh karena itu, data menunjukkan 83,3\% selalu ada prosedur pelayanan pendidikan masyarakat di PKBM.

- Dampak perencanaan program dalam pelayanan pendidikan masyarakat, dari jumlah penanggung jawab PKBM yang diteliti dalam survei hanya $83,3 \%$ menyatakan selalu. Hal ini menunjukkan bahwa dalam pelayanan pendidikan perlu adanya perencanaan yang secara matang.

- Perangkat layanan dalam program pendidikan masyarakat hendaknya dilengkapi. Dari jumlah penjab PKBM yang diteliti dalam survei $66,7 \%$ menyatakan selalu melengkapi perangkat pelayan.

- Output program pelayanan pendidikan masyarakat hendak selalu mengacu kepada kebutuhan masyarakat. Dari jumlah penjab
PKBM yang diteliti, 70,8\% menyatakan selalu berupaya untuk memenuhi tuntutan kebutuhan masyarakat dalam pembelajaran di luar sekolah.

- Proses layanan pendidikan masyarakat yang ada di PKBM dilakukan sefleksibel mungkin. Dari jumlah penjab PKBM yang diteliti, $75,0 \%$ menyatakan selalu membuat langkahlangkah yang sederhana dalam melakukan pelayanan.

- Standar layanan minimal dalam pendidikan masyarakat perlu disusun oleh penanggung jawab PKBM. Dari data yang ada menunjukkan, 75,0\% selalu mengembangkan standar minimal pelayanan.

- Mitra program dalam pelayanan pendidikan masyarakat sangat diperlukan. Dari jumlah penjab PKBM yang diteliti, 45,8\% menyatakan selalu melakukan kemitraan dalam pendidikan masyarakat.

- Program unggulan pendidikan masyarakat dari setiap lembaga mestinya ada. Dari jumlah penjab PKBM yang diteliti, 58,3\% menyatakan selalu merencanakan suatu program unggulan di lembganya.

- Monitoring dan evaluasi program pelayanan pendidikan masyarakat yang dilakukan oleh PKBM. Dari jumlah penjab yang diteliti, $75,0 \%$ menyatakan selalu melakukan monitoring dan evaluasi terhadap layanan pendidikan masyarakat.

- Kriteria keberhasilan pelayanan pendidikan masyarakat sangat diperlukan untuk melakukan penilaian, dari data survei menunjukkan bahwa para penanggung jawab, $79,2 \%$ selalu membuat kriteria keberhasilan layanan pendidikan masyarakat di lembaganya.

- Program yang distop dalam masa berlangsungnya suatu kegiatan pendidikan masyarakat di PKBM, menunjukkan 87,5\% tidak ada suatu program pendidikan masyarakat yang diberhentikan di tengah berlangsungnya kegiatan.

- Sanksi kegagalan program pelayanan pendidikan masyarakat masih belum ada ketegasan. Dari jumlah penjab PKBM yang 
diteliti, 70,8\% menyatakan selalu ada sanksi jika terjadi kegagalan dalam pelayanan program pendidikan masyarakat.

- Evaluasi dampak yang dilakukan dalam pelayanan pendidikan masyarakat belum dilakukan secara optimal. Dari jumlah penjab PKBM yang diteliti, 62,5\% menyatakan selalu melaksanakan evaluasi dampak walaupun hasil dari melaksanakan evaluasi dampak tersebut banyak yang belum ditindaklanjuti.

- Program pelayanan pendidikan masyarakat sesuai dengan visi lembaga. Dari jumlah penjab PKBM yang diteliti, 79,2\% menyatakan selalu menyusun program pelayanan sesuai dengan visi dan misi lembaga

- Sumber daya manusia dan sarana dalam pelayanan pendidikan masyarakat sangat masih kurang. Dari jumlah penjab PKBM yang diteliti, 87,5\% menyatakan selalu merencanakan pelayanan pendidikan masyarakat sesuai dengan SDM dan sarana yang ada di lembaga.

- Prestasi lembaga dalam melakukan pelayanan pendidikan masyarakat masih jauh dari yang diharapkan. Oleh karena itu, data survei menunjukkan 54,2\% selalu berke- inganan untuk memperoleh prestasi dalam pelayanan pendidikan masyarakat.

Berdasarkan uraian di atas, sistem layanan program pendidikan masyarakat pada PKBM di DKI Jakarta dapat ditunjukkan pada Gambar 1.

\section{Model Pemberdayaan Perempuan dan Peng- arusutamaan Gender}

Berdasarkan analisis data model pemberdayaan dan pengarusutamaan gender pada PKBM terhadap sampel yang di survei pada penelitian ini dapat dideskripsikan sebagai berikut.

- Kehadiran warga belajar setiap kegiatan pendidikan masyarakat yang dilaksanakan di PKBM, data survai menunjukkan 57,1\% menjawab ya, selalu hadir dalam setiap kegiatan pendidikan masyarakat.

- Aktivitas dalam program pendidikan masyarakat, dimana warga belajar yang pernah menjadi pengurus/pengelola, data survai menunjukkan $64,8 \%$ tidak pernah.

- Keikutsertaan dalam kegiatan pendidikan masyarakat yang dilaksanakan di PKBM, data survai menunjukkan $49,7 \%$ menjawab ya, selalu ikut serta.

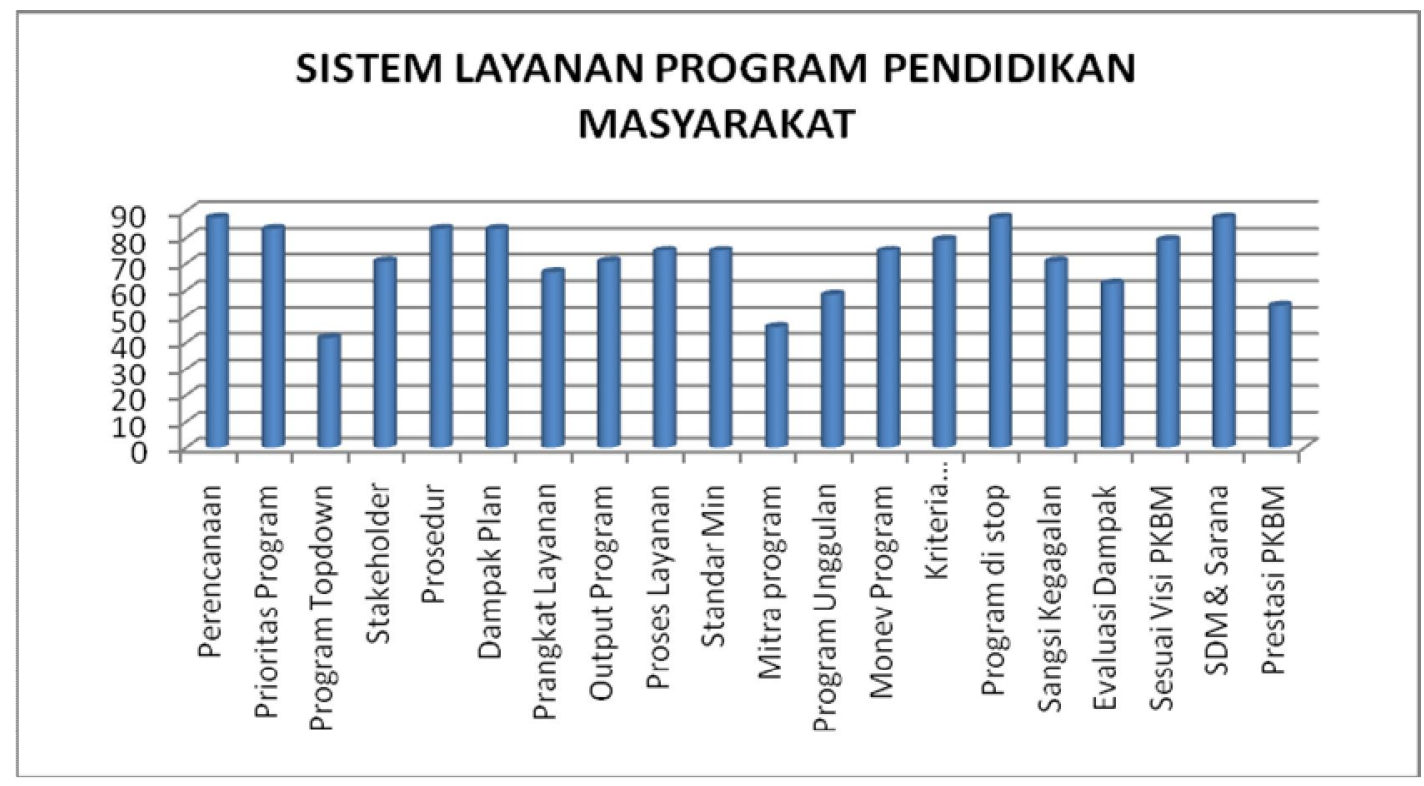

Gambar 1. Persentase dari Setiap Indikator Layanan Pendidikan Masyarakat 


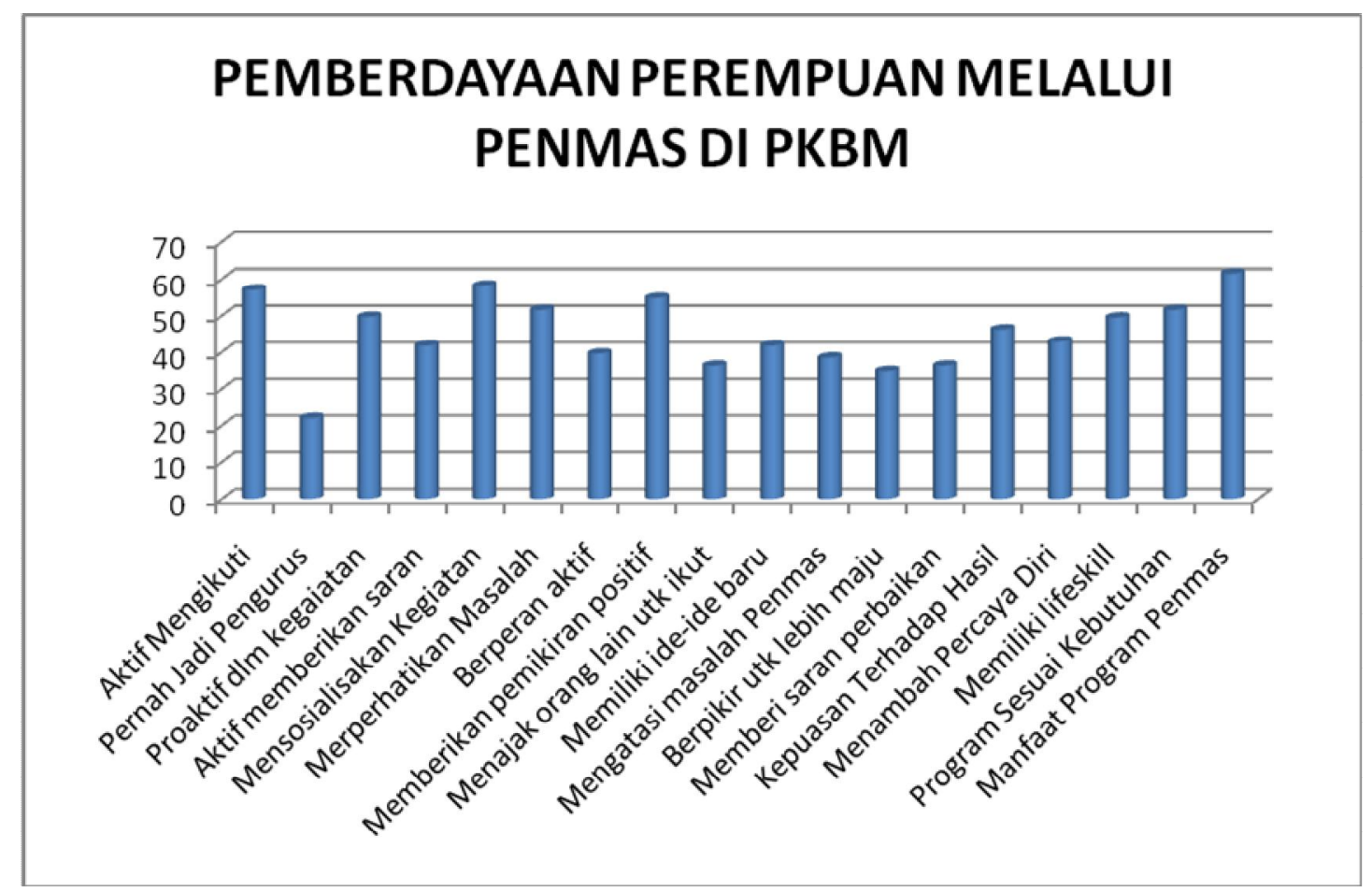

Gambar 2. Persentase dari Setiap Indikator Pemberdayaan Perempuan

- Aktif memberikan saran dalam program pendidikan masyarakat yang dilaksanakan di PKBM, data survai menunjukkan 41,8\% jawaban responden adalah kadang-kadang dalam memberikan saran.

- Melakukan sosialisasi pendidikan masyarakat di luar PKBM bersama teman, saudara atau orang lain, data survai menunjukkan $58,2 \%$ menjawab ya, selalu memberitahukan ke orang lain.

- Memperhatikan masalah-masalah yang muncul dalam pelaksanaan pendidikan masyarakat selama ini, 51,6\% menjawab ya, selalu memperhatikan pelaksanaan pendidikan masyarakat.

- Peran aktif yang dilakukan dalam setiap pendidikan masyarakat yang ada di lingkungan PKBM, jawaban responden adalah ya, selalu berperan aktif sebesar 39,6\%.

- Berpikir keras untuk lebih memajukan program pendidikan masyarakat di PKBM, jawaban responden adalah ya selalu, sebesar $54,9 \%$.

- Mengajak orang lain untuk belajar secara kelompok dalam kegiatan pendidikan masyarakat di PKBM, jawaban responden adalah kadang-kadang, sebesar 36,3\%.
- Ide baru atau pemikiran baru dalam pendidikan masyarakat di lingkungan PKBM, jawaban responden adalah kadang-kadang, sebesar $41,8 \%$.

- Mengatasi masalah yang ada dalam pelaksanaan pendidikan masyarakat di PKBM, jawaban responden adalah tidak pernah, sebesar 38,5\%.

- Memikirkan kemajuan pendidikan masyarakat yang ada sekarang di PKBM untuk lebih maju lagi, jawaban responden adalah ya selalu sebesar $34,8 \%$.

- Menyampaikan suatu usulan perbaikan terhadap pelaksanaan pendidikan masyarakat di PKBM, jawaban responden adalah ya selalu sebesar $36,3 \%$.

- Kepuasan terhadap hasil kegiatan pendidikan masyarakat yang dilaksanakan dalam PKBM selama ini, jawaban responden adalah sering sebesar $46,2 \%$.

- Mengikuti kegiatan pendidikan masyarakat menjadi lebih percaya diri, jawaban responden adalah ya, selalu sebesar $42,9 \%$.

- Mengikuti pendidikan masyarakat memperoleh keterampilan hidup yang dapat meningkatkan pendapatan keluarga, jawaban responden adalah sering sebesar $49,5 \%$. 
- Kegiatan pendidikan masyarakat yang diikuti sudah sesuai kebutuhan masyarakat, jawaban responden adalah sering sebesar $51,6 \%$.

- Manfaat dari pelaksanaan program pendidikan masyarakat yang ada di PKB, jawaban responden adalah ya selalu sebesar $61,5 \%$.

Berdasarkan uraian di atas, pemberdayaan perempuan melalui program pendidikan masyarakat pada PKBM di DKI Jakarta dapat ditunjukkan pada Gambar 2.

\section{PENUTUP}

\section{Kesimpulan}

Penelitian tentang model pemberdayaan perempuan dan pengarusutamaan gender melalui layanan pendidikan masyarakat pada PKBM di Provinsi DKI Jakarta, dapat dikemukakan beberapa kesimpulan sebagai berikut.

- Layanan program pendidikan masyarakat yang paling banyak diikuti oleh masyarakat adalah Pendidikan Kesetaraan sebesar $(61,4 \%)$ dan terendah adalah pendidikan keaksaraan $(0,9 \%)$. Sedangkan berdasarkan jenis kelamin responden dalam penelitian ini adalah perempuan sebanyak $(75,8 \%)$ dan dan laki-laki sebanyak $(24,2 \%)$

- Pemberdayaan perempuan dan pengarusutamaan gender melalui pendidikan masyarakat menunjukkan bahwa (1) perempuan aktif mengikuti kegiatan $57,1 \%$; (2) tidak jadi pengurus $64,8 \%$; (3) proaktif dalam kegiatan 49,7\%; (4) aktif memberikan saran 41,8\%; (5) meyebarluaskan kegiatan 58,2\%; (6) memperhatikan masalah $51,6 \%$; (7) berperan aktif $39,6 \%$; (8) memberikan pemikiran positif 54,9\%; (9) mengajak orang lain untuk ikut 36,3\%; (10) memiliki ide baru $41,8 \%$; (11) mengatasi masalah $38,5 \%$; (12) berpikir untuk lebih maju 34,8\%; (13) memberikan saran perbaikan $36,3 \%$; (14) kepuasan terhadap hasil 46,2\%; (15) menambah percaya diri 42,9\%; (16) memiliki keterampilan hidup 49,5\%; (17) program sesuai dengan kebutuhan 51,6\%; dan (18) manfaat mengikuti program pendidikan masyarakat $61,5 \%$.

- Model pemberdayaan perempuan dan peng- arusutamaan gender melalui layanan pendidikan masyarakat dipandang sangat strategis, sehingga akan menghasilkan sumberdaya manusia yang berkualitas, berakhlak mulia, cerdas, terampil dan mandiri.

\section{Saran}

- Pembina kelembagaan PKBM, dalam hal ini Dinas Pendidikan Provinsi DKI Jakarta berkewajiban melalukan pembinaan terhadap para penanggung jawab PKBM yang ada dilingkungan DKI Jakarta umumnya dan khususnya para Kepala Seksi PNFI, untuk meningkatkan layanan pendidikan masyarakat di PKBM lebih berkualitas karena sangat strategis dalam pemberdayaan perempuan dan pengarusutamaan gender.

- Kementrian Pendidikan dan Kebudayaan melalui Direktorat Pendidikan Masyarakat Direktorat Jenderal PAUDNI diharapkan mampu mendorong pemberdayaan perempuan dan pengarusutamaan gender ini dengan berbagai kebijakan tentang programprogram pendidikan masyarakat yang lebih praktis dan efektif. Program ini diharapkan menghasilkan sumber daya manusia yang berkualitas, berakhlak mulia, cerdas, terampil dan mandiri.

- Para peneliti berdasarkan hasil kajian teori penelitian ini ada yang masih perlu dilakukan penelitian lebih lanjut, yang terkait dengan efektivitas model pemberdayaan perempuan melalui pendidikan masyarakat pada PKBM di DKI Jakarta.

\section{UCAPAN TERIMA KASIH}

Ucapan terima kasih disampaikan kepada berbagai pihak yang telah membantu terlaksanakannya penelitian. Mereka adalah pemberi sponsor, narasumber, responden, sejawat, dan lain-lain yang jumlahnya cukup banyak. Tanpa mereka, penelitian ini mustahil dilaksanakan. Harapannya, penelitian memberikan kontribusi yang signifikan bagi pemberdayaan perempuan. 
DAFTAR PUSTAKA

Departemen Pendidikan Nasional. 2006. Profil Direktorat Pendidikan Masyarakat. Jakarta: Ditjen. PNFI Depdiknas.

Hamalik, O. 2000. Model-model Pengembangan Kurikulum. Bandung: SPs Universitas Pendidikan Indonesia.

Instruksi Presiden Nomor 9 tentang Pengarusutamaan Gender. 2000. Jakarta: Depdiknas.

Kompas, 12 Maret 2011. Angka Kematian Ibu (AKI) dan Masalah Sosial Perempuan.

Kementerian Pendidikan Nasional. 2010. Rencana Strategis. Jakarta: Kemendiknas.
Kindervatter, S. 1979. Nonformal Education as an Empowering Process with Case Studies from Indonesia and Thailand. USA: Massachusetts.

Sihombing, U. 2000. Pendidikan Luar Sekolah Manajemen Strategis, Konsep Kiat dan Pelaksanaan. PD. Mahkota Jakarta.

Sugiyono, 2007. Metode Penelitian Kuantitatif, Kualitatif dan $R \& D$. Bandung: Alfabeta.

Undang-Undang Republik Indonesia Nomor 25 tentang Program Pembangunan Nasional. 2000. Jakarta: Depdiknas.

Yulaelawati, Ella. 2009. Pendidikan Masyarakat untuk Pemberdayaan. Jakarta: Ditjen. PNFI Depdiknas. 